\title{
BAKTERI RESISTEN MERKURI (Hg) PADA PLAK GIGI PASIEN \\ DENGAN TUMPATAN AMALGAM DI PUSKESMAS BAHU
}

\author{
Karen Tizia Mogi \\ Billy Kepel \\ Widdhi Bodhi

\begin{abstract}
Bagian Kimia Fakultas Kedokteran Universitas Sam Ratulangi
Email: karenmogi@yahoo.com
\end{abstract}

\begin{abstract}
Amalgam is an alloy of mercury with various metals which used for dental amalgam fillings since 150 years ago. It is still popular because of it's strength and durability. However, it also has issue about it's safety due to releasing of mercury inside oral cavity. Long time of exposure to mercury will result in resistant mercurial. Bacteria have ability to reduce $\mathrm{Hg}^{2+}$ to $\mathrm{Hg}^{0}$ by mercury reductase enzyme, changing toxicity to non-toxic form. We obtained the dental plaque from 5 patients who has been using amalgam for 5 years or more at Puskesmas Bahu. The dental plaque were stored inside the sterile glass tube with $0.9 \% \mathrm{NaCl}$ solution and then tested for mecury resistant bacteria and identified bacteria. We founded 15 isolates were resistant to mercury. Then we did physiology, morphology, and biochemistry tests. There are 8 genus of bacterias which has ability to reduce mercury from dental plaque of patient with amalgam fillings.

Keywords: Amalgam, Mercury Resistant Bacteria, Dental Plaque
\end{abstract}

\begin{abstract}
Abstrak: Amalgam merupakan campuran logam, yang diantaranya adalah merkuri sudah digunakan sejak 150 tahun yang lalu oleh kedokteran gigi sebagai penambal gigi berlubang dan sampai sekarang amalgam masih digunakan oleh dokter gigi karena merupakan bahan tambalan yang kuat dan tahan lama. Namun resiko utama amalgam adalah pelepasan uap merkuri yang mungkin terjadi selama penggunaannya di rongga mulut. Penggunaan amalgam ini memicu munculnya bakteri resisten terhadap merkuri dimana bakteri mampu untuk mereduksi ion $\mathrm{Hg}^{2+}$ menjadi $\mathrm{Hg}^{0}$ oleh enzim merkuri reduktase, yang sebelumnya bersifat toksik menjadi kurang toksik. Tujuan dari penelitian untuk mengetahui bakteri resisten merkuri pada plak gigi pasien dengn tumpatan amalgam. Desain penelitian adalah metode deskriptif eksploratif. Sampel yang diambil dalam penelitian ini adalah 5
\end{abstract}


koloni bakteri resisten merkuri pada plak gigi dari pasien yang telah menggunakan tumpatan amalgam minimal 5 tahun yang berkunjung ke Puskesmas Bahu. Spesimen yang didapatkan dimasukkan ke dalam tabung reaksi steril yang berisi larutan $\mathrm{NaCl} 0.9 \%$ segera dibawa ke laboratorium untuk dilakukan uji resistensi merkuri dan identifikasi bakteri. Isolasi isolat bakteri resisten merkuri pada 5 sampel, diperoleh 15 isolat. Selanjutnya dilakukan identifikasi bakteri melalui uji morfologi, uji fisiologi, dan uji biokimia. Hasil uji yang dilakukan ditemukan 8 genus bakteri yang dapat diidentifikasi.

Kata Kunci: Amalgam, Bakteri Resisten Merkuri, Plak Gigi

Amalgam merupakan campuran logam, yang diantaranya adalah merkuri sudah digunakan sejak 150 tahun yang lalu oleh kedokteran gigi sebagai penambal gigi berlubang. ${ }^{1,2}$ Sampai sekarang amalgam masih digunakan oleh dokter gigi karena merupakan bahan tambalan yang kuat, tahan lama, harganya murah, dapat beradaptasi dengan baik dengan cairan mulut, dan pengerjaannya hanya dalam satu kali kunjungan. ${ }^{1,3}$

Salah satu resiko utama amalgam adalah pelepasan uap merkuri yang mungkin terjadi selama penggunaannya di rongga mulut. Merkuri berbentuk cair pada temperatur ruang, titik lelehnya $-39^{\circ} \mathrm{C}$, mudah menguap dan bersifat toksik bagi jaringan dan organ di dalam tubuh manusia. Selain bagi individu yang menggunakan amalgam, paparan merkuri juga merupakan bahaya bagi dokter gigi dan perawat gigi ${ }^{4}$ Pemaparan merkuri baik akut maupun kronis dapat mempenagruhi kesehatan suatu populasi secara bermakna terutama anak-anak ${ }^{5}$ dan ibu hamil. ${ }^{3}$

Penggunaan amalgam gigi di Indonesia masih digunakan secara luas di klinik-klinik umum, terutama di wilayah terpencil, dan menjadi bagian peralatan kesehatan standar yang dibagikan setiap tahun di Puskesmas. ${ }^{6}$

Survei Kesehatan Rumah Tangga (SKRT) tahun 2004 yang dilakukan oleh Departemen Kesehatan menyatakan bahwa prevalensi penyakit gigi dan mulut adalah tertinggi meliputi $60 \%$ penduduk. ${ }^{7,8}$ Plak gigi adalah deposit lunak yang melekat pada permukaan gigi, tumpatan, maupun kalkulus. ${ }^{9,10,11}$ Deposit ini berisi kumpulan bakteri yang berkembang biak didalam suatu matriks, tidak dapat dibersihkan hanya dengan berkumur-kumur saja, tetapi dapat dibersihkan secara mekanis yaitu dengan menyikat gigi. ${ }^{10,11}$

Berbagai penelitian telah membuktikan bahwa plak gigi merupakan penyebab utama terjadinya karies gigi dan penyakit periodontal. ${ }^{7,8,10,11}$ secara klinis terbukti bahwa mulut yang menderita penyakit periodontal selalu memperlihatkan adanya penimbunan plak yang jauh lebih banyak daripada mulut yang sehat. ${ }^{10}$ Penelitian lain menunjukan bahwa jumlah plak gigi dan kalkulus pada mulut yang menderita penyakit periodontal kira-kira 10 kali lebih banyak dibandingkan mulut yangs sehat. ${ }^{12}$

Pelepasan uap merkuri dari amalgam yang terjadi selama penggunaannya di dalam rongga mulut memicu munculnya bakteri resisten terhadap merkuri dimana bakteri mampu untuk mereduksi ion $\mathrm{Hg}^{2+}$ menjadi $\mathrm{Hg}^{0}$ yang sebelumnya bersifat toksik menjadi kurang toksik. Bakteri yang resisten terhadap merkuri ini mempunyai kemampuan untuk menurunkan toksisitas atau detoksifikasi merkuri melalui mekanisme enzimatis melalui bantuan enzim merkuri reduktase. ${ }^{4,13}$

Puskesmas Bahu Kecamatan Malalyang memiliki cakupan wilayah kerja yang terdiri dari 5 kelurahan dengan 31 lingkungan dengan jumlah 32.594 orang, dan 7.462 KK, dimana penggunaan amalgam juga masih digunakan pada pasien-pasien yang datang 
di poli gigi. Berdasarakan pemaparan yang ada maka penulis tertarik untuk melakukan penelitian tentang bakteri resisten merkuri pada plak gigi pasien dengan tumpatan amalgam.

\section{Metode Penelitian}

Penelitian ini menggunakan metode deskriptif eksploratif, dimana penelitian ini dilakukan pada bulan Agustus 2012 - Desember 2012, dan waktu pengambilan data dilakukan pada bulan November 2012 - Desember 2012. Pengambilan sampel di Puskesmas Bahu Kecamatan Malalayang dan selanjutnya sampel di bawa ke Laboratorium Bioteknologi Fakultas MIPA Universitas Sam Ratulangi untuk dilakukan uji bakteri resisten merkuri dan identifikasi bakteri. Populasi dalam penelitian adalah bakteri pada plak gigi pasien yang berkunjung di poli gigi Puskesmas Bahu, Kota Manado. Sedangkan sampel yang diambil dalam penelitian ini adalah berdasarkan populasi yang ada, diambil 5 koloni bakteri dari plak gigi pasien di poli gigi dengan tumpatan amalgam, minimal sudah menggunakan tumpatan amalgam selama 5 tahun. Variabel penelitian disini adalah bakteri resisten merkuri.

Penelitian ini dilakukan melalui beberapa tahap, yaitu tahap isolasi bakteri resisten merkuri dimana bertujuan untuk mengisolasi bakteri-bakteri yang ada pada sampel plak gigi. Prosedur kerjany, koloni ditumbuhkan pada media Nutrient Agar yang sudah mengandung merkuri setelah perhitungan total koloni, kemudian dipindahkan pada media agar miring dengan menggunakan jarum ose sebagai kultur sediaan (isolat) dan selanjutnya disimpan pada suhu $4^{\circ} \mathrm{C}$. Setelah itu dilakukan seleksi kultur bakteri, seleksi ini dilakukan dengan cara inokulasi kultur bakteri sampel dalam media seleksi padat yang mengandung $\mathrm{HgCl}_{2}$ dalam beberapa kadar yang berbeda yaitu 10, 20, dan $40 \mathrm{ppm}$ dan diinkubasi pada temperatur $37^{\circ} \mathrm{C}$ selama 48 jam. Selanjutnya diamati jumlah koloni yang tumbuh. Setiap tahap seleksi kultur bakteri ini dilakukan pada setiap sampel.

Selanjutnya tahap identifikasi dengan menggunakan uji morfologi dilakukan dengan perwarnaan Gram, dimana pengujian ini bertujuan untuk menentukan karateristik mikroskopik isolat uji, baik reaksinya terhadap pewarnaan gram, bentuk sel dan ukurannya. Kemudian dilakukan uji fisiologi dimana bertujuan untuk mengetahui apakah bakteri yang diuji dapat melakukan pergerakan (motil) atau tidak (nonmotil). Selanjutnya dilakukan uji biokimia yang terdiri dari uji indol menggunakan media semi padat yang kaya akan triptofan. $\mathrm{Uji}_{2} \mathrm{~S}$ dengan menggunakan media Triple Sugar Iron Agar yang bertujuan untuk menentukan kemampuan isolat uji dalam memproduksi $\mathrm{H}_{2} \mathrm{~S}$ melalui reduksi thiosulfat. Uji Fermentasi Karbohidrat, untuk menentukan kemampuan bakteri dalam mendegradasi dan memfermentasikan karbohidrat tertentu dengan memproduksi asam atau asam dan gas. Uji katalse dengan menggunakan media Nutrient Broth untuk menentukan kemampuan bakteri untuk mendegradasi hidrogen peroksida melalui produksi enzim katalase. Uji sitrat menggunakan Simmons's Citrate Agar bertujuan untuk menentukan kemampuan bakteri dalam menggunakan sitrat sebagai sumber karbon dan energi. Dan yang terakhir uji lysine dekarboksilase menggunakan media Lysine Iron Agar untuk melihat kemampuan bakteri melakukan dekarboksilasi dalam asam amino berupa lisin melalui produksi enzim dekarboksilase.

Setelah serangkaian uji Morfologi, Fisiologi, dan uji Biokimia, maka data ditabulasi dalam tabel kemudian hasil ini dibandingkan dengan petunjuk yang terdapat dalam Bergey's Manual Determinative of Bacteriology. 


\section{Hasil Penelitian}

Pemilihan populasi bakteri berdasarkan pada pembentukan koloni bakteri yang paling baik dan yang paling mudah untuk diisolasi. Setiap sampel dibuat 3 buah isolat pada cawan petri yang berbeda dengan menggunakan kode PG 1.1, PG 1.2, PG 1.3, PG 2.1, PG 2.2, PG 2.3, PG 3.1, PG 3.2, PG 3.3, PG 4.1, PG 4.2, PG 4.3, PG 5.1, PG 5.2, PG 5.3. Koloni bakteri yang terbentuk adalah berwarna putih keruh. Setelah itu koloni yang telah terbentuk di inokulasikan ke media agar miring masing-masing 1 isolat untuk tiap cawan petri. Isolat yang terbentuk semuanya berwarna putih keruh yang selanjutnya isolat yang terbentuk digunakan untuk dilakukan identifikasi bakteri. Pada konsentarsi 10ppm, 20ppm, dan 40ppm didapatkan ada pertumbuhan bakteri pada tiap isolat. Oleh karena itu dipilih konsentrasi 40ppm karena merupakan konsentrasi yang paling tinggi dimana didapatkan isolat yang tumbuh.

Hasil uji morfologi yang didapatkan pada pewarnaan gram adalah Isolat PG 1.1, PG 1.3, PG 2.1, PG 2.2, PG 2.3, PG 3.2, dan PG 5.1 didapatkan kokus Gram positif. Isolat PG 1.2, PG 3.1, PG 3.3, PG 4.1, PG 4.2, PG 4.3, PG 5.2, dan PG 5.3 didapatkan kokus Gram negatif.

Hasil uji fisiologi 15 isolat pada media miomedium semi padat didapatkan isolat $\mathrm{PG}$ 1.2, PG 2.2, PG 2.3, PG 3.1, PG 3.2, PG 3.3, PG 4.1 dan PG 5.1 menunjukkan hasil yang positif yaitu bakteri menunjukkan pertumbuhan menyebar baik di sekitar tempat penusukan sampai di permukaan media.

Hasil uji biokimia. Hasil uji indol yang didapatkan, sebanyak 12 isolat yang memberikan hasil positif yaitu, terbentuk cincin berwarna merah di permukaan media setelah diberikan sebanyak 5 tetes reagen kovac's dan dibiarkan selama 10 menit. Pada uji $\mathrm{H}_{2} \mathrm{~S}$ dengan menggunakan media TSIA (Triple Sugar Iron Agar) didapatkan hasil yang positif pada 11 isolat yang terbukti dengan terbentuknya endapan berwarna hitam pada dasar dari media yang menunjukkan bahwa bakteri dapat membentuk $\mathrm{H}_{2} \mathrm{~S}$. Hasil uji Fermentasi Karbohidrat menunjukkan sebanyak 9 isolat yang positif, dimana menunjukkan bahwa dapat memfermentasikan semua jenis karbohidrat dan juga menghasilkan gas $\mathrm{CO}_{2}$ sebagai sisa proses fermentasi.

Hasil uji katalase pada semua isolat yang ditumbuhkan pada media Nutrient Broth menunjukkan hasil positif pada 10 isolat dimana terjadi pembentukan gelembung gas. Hal ini menunjukkan bahwa bakteri memiliki enzim katalase yang berfungsi menguraikan $\mathrm{H}_{2} \mathrm{O}_{2}$ yang ditambahkan ke koloni bakteri menjadi $\mathrm{H}_{2} \mathrm{O}$ dan $\mathrm{O}_{2}$. Hasil uji sitrat menunjukkan hasil yang positif pada 2 isolat dimana terjadi perubahan warna media dari hijau menjadi warna biru. Hasil uji lysine dekarboksilase yang menunjukkan hasil positif adalah pada 8 isolat dimana media menjadi berwarna lembayung (ungu) pada semua bagian baik di dasar media maupun di bagian media yang miring.

Setelah hasil dari identifikasi bakteri yang meliputi uji morfologi, fisiologi, dan biokimia diperoleh, semua hasil ini digabungkan dan digunakan untuk menentukan bakteri yang terkandung pada masing-masing isolat. Penentuan bakteri dilakukan dengan membandingkan hasil uji yang diperoleh dengan data-data yang terdapat didalam buku Bergey's Manual Determinative of Bacteriology.

Isolat PG 1.1 pada pewarnaan Gram merupakan pewarnaan Gram positif dengan bentuk kokus. Berdasarkan bentuknya maka isolat ini kemungkinan dapat dikelompokkan kedalam tiga genus bakteri, yaitu Gamella, Lactococcus, dan Sterptococcuss. Dimana ketiga bakteri ini merupakan bakteri Gram positif, nonmotile, dengan uji katalase negatif. ${ }^{14}$ 
Isolat PG 1.2, PG 3.3 dan PG 4.1 pada pewarnaan Gram menunjukan bakteri kokus Gram negatif. Bakteri motil. Pada uji biokimia didapatkan indol positif, katalase negatif pada PG 1.2 dan PG 3.3 sedangkan pada PG 4.1 positif. PG 1.2 Tidak memproduksi $\mathrm{H}_{2} \mathrm{~S}$ sedangkan PG 3.3 dan PG 4.1 memproduksi $\mathrm{H}_{2} \mathrm{~S}$. Uji lysine dekarboksilase positif hanya pada isolat PG 1.2. Dari semua hasil pengujian ini, disimpulkan bahwa ketiga isolat ini dapat digolongkan kedalam bakteri Acitenobacter. ${ }^{14}$

Isolat PG 1.3 dan PG 2.1 pada pewarnaan Gram merupakan bakteri kokus Gram positif. Pada uji motilitas didapatkan bakteri ini nonmotil. Selain itu, hasil uji biokimia diperoleh uji indol yang positif dan katalase positif maka dapat disimpulkan bahwa bakteri ini adalah Staphylococcus. ${ }^{14}$

Isolat PG 2.2, PG 2.3, PG 3.2 dan PG 5.1 menunjukkan gambaran pewarnaan Gram yang sama yaitu kokus gram positif. Keempat bakteri ini menunjukkan hasil positif pada uji motil dan hasil positif pada uji indol. Selain itu, hasil uji biokimia keempatnya juga serupa yaitu uji katalase positif. Dari hasil uji morfologi, uji fisiologi, dan uji biokimia keempat isolat ini dapat dikelompokan kedalam bakteri Marinococcus, Micrococcus, dan Planococcus. ${ }^{14}$

Isolat PG 3.1 merupakan bakteri kokus Gram negatif pada pewarnaan Gram. Pada uji motil didapatkan hasil positif. Uji indol, uji katalase, dan uji $\mathrm{H}_{2} \mathrm{~S}$ juga didapatkan hasil positf. Sedangakan hasil negatif didapatkan pada uji sitrat dan uji lysine dekarboksilase. Berdasarkan hasil tersebut, maka disimpulkan isolat ini kedalam bakteri Alcaligenes. ${ }^{14}$

Isolat PG 4.2 pada pewarnaan Gram merupakan bakteri kokus gram negatif. Berdasarkan bentuknya yang khas maka disimpulkan bahwa bakteri dalam isolat ini adalah Morococcus. Kesimpulan ini ditunjang oleh uji motil negatif, uji indol, uji $\mathrm{H}_{2} \mathrm{~S}$, dan uji katalase serta uji lysine dekarboksilase menunjukkan hasil positif, sedangkan uji sitrat negatif. ${ }^{14}$

Isolat PG 4.3 dan 5.2 merupakan bakteri kokus Gram negatif pada pewarnaan gram. Keduanya member hasil negatif pada uji motil, sedangkan hasil positif pada uji $\mathrm{H}_{2} \mathrm{~S}$ dan uji Katalase. Berdasarkan hasil yang ada maka disimpulkan isolat ini kedalam bakteri Phenylobacterium. ${ }^{14}$

Isolat PG 5.3 menunjukkan gambaran bakteri kokus Gram negatif. Pada uji motil maupun uji indol menunjukkan hasil yang negatif. Memproduksi $\mathrm{H}_{2} \mathrm{~S}$. Uji katalase dan uji lysine dekarboksilase menunjukkan hasil positif. Maka dapat disimpulkan bahwa bakteri dalam isolat ini adalah Brucella. ${ }^{14}$

\section{Pembahasan}

Kemampuan reduksi setiap kultur bakteri yang diperoleh terhadap merkuri berbeda. Perbedaan resistensi ini berhubungan dengan mekanisme respon populasi bakteri terhadap merkuri dengan metabolisme sel melalui sistem operon resisten dalam plasmid untuk menginduksi reduksi merkuri ${ }^{15}$ Suhu dan $\mathrm{pH}$ merupakan faktor lingkungan yang sangat menentukan kehidupan bakteri. Suhu yang rendah dapat menyebabkan aktivitas enzim menurun dan jika suhu terlalu tinggi dapat mendenaturasi protein enzim. Pada suhu optimum pertumbuhan bakteri berlangsung dengan cepat. Diluar kisaran suhu optimum pertumbuhan bakteri menjadi lambat atau tidak ada pertumbuhan. ${ }^{16}$ 
Setelah dilakukan uji resistensi bakteri terhadap merkuri, tahap selanjutnya yang dilakukan adalah isolasi dan identifikasi bakteri resisten merkuri yang meliputi uji morfologi, uji fisiologi dan uji biokimia. Setelah bakteri diisolasi dalam 15 isolat yang diberikan $\mathrm{HgCl} 2$ maka segera dilakukan identifikasi terhadap bakteri di tiap isolat.

Isolat PG 1.1 berdasarkan hasil penelitian yang ada maka isolat menunjukkan kemungkinan bakteri ini Gamella, Lactococcus, dan Sterptococcus. Pada pewarnaan Gram ketiga bakteri ini merupakan pewarnaan gram positif dengan bentuk kokus. Dari ketiga bakteri, Streptococcus merupakkan bakteri yang memiliki kesaamaan dari isolat ini, dimana tumbuh di medium padat sebagai koloni diskoid dengan diameter 0,5-2,0 $\mu \mathrm{m}$, nonmotil. Katalase negatif. Dan bersifat fakultatif anaerob. ${ }^{14,17}$

Isolat PG 1.2, PG 3.3 dan PG 4.1 menunjukan bakteri Acitenobacter, bakteri aerob Gram negatif yang tersebar luas didalam tanah dan air serta kadang-kadang dapat dibiakkan dari kulit, membran mukosa, sekret, dan lingkungan rumah sakit. Biasanya bakteri ini tampak berbentuk coccobacill, kokus, maupun batang dan kadang-kadang bakteri tampak bersifat Gram positif. Diameter koloni 0,1-0,3 $\mu$ m. Suhu pertumbuhan optimal adalah $33-35^{\circ} \mathrm{C}$. Bakteri ini termasuk pada bakteri yang tidak mampu bergerak (nonmotil). Katalase, oksidase dan produksi $\mathrm{H}_{2} \mathrm{~S}$ bersifat positif. ${ }^{17}$

Isolat PG 1.3 dan PG 2.1 menunjukkan bakteri Staphylococcus merupakan sferis Gram positif, biasanya tersusun dalam kelompok seperti buah anggur yang tidak teratur dengan diameter 0,5-2,0 $\mu \mathrm{m}$. Termasuk pada bakteri nonmotil. Kebutuhan terhadap oksigen termasuk aerob. Pada umumnya bakteri ini tumbuh pada media yang mengandung $10 \% \mathrm{NaCl}$ dengan suhu optimal yaitu $30-37^{\circ} \mathrm{C}$. Katalase, oksidase dan produksi $\mathrm{H}_{2} \mathrm{~S}$ bersifat positif. Beberapa tipe staphylococcus merupakan flora normal kulit dan membran mukosa manusia. Tipe lainnya bersifat patogen. ${ }^{14,17}$

Isolat PG 2.2, PG 2.3, PG 3.2 dan PG 5.1 menunjukkan kemungkinan diidentifikasi kedalam bakteri Marinococcus, Micrococcus, dan Planococcus. Berdasarkan hasil yang ada maka Micrococcus merupakkan bakteri yang dapat mewakili keempat hasil isolat diatas. Dimana bakteri ini merupakan bakteri kokus gram positif, dengan diameter koloni 0,2-2 $\mu \mathrm{m}$. Koloni muncul di atas permukaan media NA. Koloni berwarna kuning. Permukaan koloni mengkilat. Suhu pertumbuhan optimum $25-37^{\circ} \mathrm{C}$. Kebutuhan terhadap oksigen termasuk aerob dan anaerob. Termasuk pada bakteri yang mampu bergerak. Katalase, oksidase dan produksi $\mathrm{H}_{2} \mathrm{~S}$ bersifat positif. Mampu tumbuh baik pada media dengan salinitas $5 \%$ NaCL. ${ }^{14}$

Isolat PG 3.1 menunjukkan bakteri Alcaligenes batang Gram negatif oksidasepositif, berbentuk batang maupun kokus berukuran 0,5-1,0 x 0,5-2,6. Bakteri ini mempunyai flagel peritrika dan motil. Termasuk dalam bakteri aerob obligat namun beberapa jenis lainnya termasuk bakteri anaerob dengan bantuan nitrat. Suhu optimal pertumbuhan bakteri ini $20-37^{\circ} \mathrm{C}$. Koloni pada nutrient agar tidak berpigmen. Pada uji katalase dan oksidase menunjukan hasil positif., sedangakan indol negatif. Biasanya bakteri ini terdapat pada air dan tanah. Bakteri ini dapat menjadi bagian dari flora normal pada manusia, dan telah diisolasi dari alat respirator, nebulizer, dan sistem dialysis ginjal. Bakteri ini juga kadang diisolasi dari urine, darahm cairan spinal, luka dan abses. ${ }^{17}$

Isolat PG 4.2 menunjukkan bakteri Morococcus yang merupakan Gram negatif berbentuk bulat dengan diameter $<1 \mu \mathrm{m}$ terikat erat bersama-sama, seperti agregat buah murbei 10-20 sel. Bersifat nonmotil dan nonsporing. faktor pertumbuhan yang kompleks tidak diperlukan. Koloni pada sukrosa agar memberikan reaksi berwarna hitam jika ditambah dengan yodium. Kisaran suhu optimal untuk pertumbuhan bakteri ini adalah 23- 
$42^{\circ} \mathrm{C}$. Uji katalase dan oksidase positif. Produksi nitrat hanya sedikit pada bakteri ini. $\mathrm{H}_{2} \mathrm{~S}$ positif. $^{14}$

Isolat PG 4.3 dan 5.2 menunjukkan bakteri Phenylobacterium merupakan bakteri Gram negatif berbentuk kokus dengan ukuran 0,7-1,0 x 1,0-2,0 $\mu \mathrm{m}$. Umumnya bakteri ini tunggal, berpasangan, ataupun membentuk rantai pendek. Bakteri ini tidak memiliki motil. Pertumbuhan dari bakteri pada agar termasuk lambat dan koloni yang tumbuh juga kecil (1-2mm sesudah 2-3minggu). Koloni biasanya halus, cembung, lembab, dengan permukaan mengkilap. Suhu optimal untuk pertumbuhan bakteri ini adalah $29-30^{\circ} \mathrm{C}$. Pertumbuhan tidak terjadi pada suhu 4 dan $37^{\circ} \mathrm{C}$. Pada suhu $37^{\circ} \mathrm{C}$ kultur bakteri akan mati dalam beberapa hari. Berdasarkan uji biokimia maka didapatkan uji katalase positif, dan uji oksidase positif lemah. Urea dan Indol negatif. ${ }^{14}$

Isolat PG 5.3 menunjukkan gambaran bakteri Brucella yang merupakan bakteri Gram negatif dengan bentuk kokus sampai batang dengan panjang $12 \mu \mathrm{m}$ dengan sebagian besar berbentuk coccobacill pendek. Bersifat anaerob, nonmotil dan tidak membentuk spora. Bakteri ini memetabolisme karbohidrat tetapi tidak menghasilkan baik asam maupun gas dalam jumlah yang cukup untuk diklasifikasi. Katalase dan oksidase diproduksi oleh keempat spesies yang mengifeksi manusia. Bakteri ini cukup sensitif terhadap panas dan asam. Suhu optimal adalah $37^{\circ} \mathrm{C}$ dan pertumbuhan dapat terjadi pada suhu 20 dan $40^{\circ} \mathrm{C} .{ }^{17}$

Suatu bakteri digolongkan bakteri resisten merkuri apabila bakteri tersebut dapat bertahan pada konsentrasi merkuri $10 \mathrm{ppm}$ atau lebih. Hal ini dapat terjadi karena sampel diambil berdekatan dengan tambalan amlgam, yang mana diketahui bahwa amalgam merupakan campuran beberapa logam (alloy) dengan komposisi terdiri dari merkuri, perak (67-74\%), timah (25-28\%), dan tembaga (0-6\%), serta beberapa elemen tambalan yang akan meningkatkan sifat fisik dan mekanik bahan seperti inidium, palladium, dan selenium sehingga dapat disimpulkan bahwa bakteri ini memiliki gen resisten merkuri. ${ }^{18}$

\section{Kesimpulan dan Saran}

Berdasarkan hasil penelitian yang telah didaptkan maka disimpulkan, hasil isolasi bakteri resisten merkuri pada plak gigi pasien di poli gigi Puskesmas Bahu maka diperoleh 15 jenis isolat yang memiliki kemampuan mereduksi merkuri, dimana Micrococcus, Sterptococcus, Staphylococcus, Acitenobacter, Alcaligenes, Brucella, Morococcus dan Phenylobacterium merupakan 8 genus bakteri yang resisten merkuri, berdasarkan uji morfologi, uji fisiologi, dan uji biokimia dari ke 15 isolat.

Saran untuk para praktisi di bidang kedokteran gigi, hasil penelitian ini menunjukkan adanya bakteri resisten merkuri pada pasien dengan tumpatan amalgam. Oleh karena itu sebaiknya perlu dipertimbangkan kembali pemilihan bahan dasar tambalan gigi yang bebas merkuri. Selain itu untuk lebih jauh mengetahui peran bakteribakteri resisten merkuri, maka sebaiknya dilakukan penelitian lebih lanjut dengan menggunakan metode yang lainnya, yaitu biologi molekuler serta menambah uji-uji biokimia yang lainnya selain uji-uji yang telah digunakkan peneliti. 


\section{Ucapan Terima Kash}

Ucapan terima kasih diucapkan pada DR. Dr Billy Kepel, MMedSc; Widdhi Bodhi S.Si, M.Kes, Apt; dr.Christian J.K Hartono; Beivi Kolondam, S.Si, M.Si, MS; Nurmiati, S.Si, DR. Dra. Fatimawali, M.Si, Apt (penguji I) dan Dr. Aaltje Manampiring, M.Kes (penguji II), dan pada semua pihak yang dengan baik secara langsung telah menumbuhkan idea tau gagasan dalam pemikiran penulis sehingga dapat menyelesaikan artikel ini

\section{Kepustakaan}

1. ADA. Dental Amalgam: Update on safety concerns. J ADA 1988 Apr;129:494-496

2. Colson GD. A safe protocol for amalgam removal. Journal of Environmental and Public Health 2011 Nov;2012:1-2

3. Rathore M, Singh A, Pant AV. The dental amalgam toxicity fear: a myth or actually.Toxicol Int 2012 May-Aug;19(2):81-88

4. Bindslev HP, Magos L, Holmstrup, Bindslev AD, Sumawinata N, editor. Tambalan amalgam berbahaya untuk kesehatan. Jakarta: EGC; 1998

5. Bellinger $C D$, Trachtenberg $F$, Zhang $A$, Tavares $M$, Daniel $D$, McKinlay S. Dental amalgam and psychosocial status. J Dent Res 2008;87(5):470-474

6. Laporan WHO Mengimbau "Pengurangan" Amalgam Gigi Sedunia; Terobosan Menuju Penghapusan Merkuri Dalam Kesehatan Gigi [Online] 2011 Oct 14 [cited 2012 Oct 20] Available from: URL:http://en.wikipedia.org/wiki/Amalgam_(dentistry)

7. Hermina V. Efektifitas metode pengajaran cara menyikat gigi terhadap penurunan indeks plak anak usia 3-5 tahun. Dentika Dental Journal 2010;15(1):42-45.

8. Zenab, Mardiastuti HW. Anny VP. Logawa B. Uji antibakteri siwak (Salvadora persica Linn) terhadap Sterptokokus mutans dan Bacteroides melaninogenicus. Makara Kesehatan. 2004 8(2);37-40

9. Dental plaque. 2012 Oct 27 [cited 2012 Nov 6]. Available from: http://en.wikipedia.org/wiki/Dental_plaque

10. Edwina AM. Bechal JS. Dasar-dasar karies penyakit dan penanggulannya. Dalam: Sumawinta N. Faruk S, editors. Jakarta: EGC; 1999.h.2-5.

11. Setyawan S. Adi SM. Saluhiyah Z. Wijanrko B. Istiarti T. Ginanjar P. Studi intervensi pemakaian larutan disklosing oleh murid sendiri dalam mengontrol plak gigi. Semarang: Universitas Diponegoro;1999.

12. Lobene R. Clinical studies of plaque control agents. J Dent Res. Boston 1979:58(12);2381-2388

13. Anne O. Interaction of human commensal bacteria with amalgam-derived mercury: the scince and its implications for infectious disease and neurotoxicology. [Athens (GA)]:Georgia University; 2006.

14. Holt J.G, N.R. Krieg, P.H.A. Sneath, J.T. Staley, S.T. Williams. 1994. Bergey's Manual of Determinative Bacteriology, $9^{\text {th }}$ Edition. USA: Williams and Wilkins.

15. Fatimawali, Fatmawati B, Irawan Y. Isolasi dan Identifikasi Bakteri Resisten Merkuri Dari Muara Sungai Sario yang dapat digunakan untuk detoksifikasi limbah Merkuri. Jurnal Ilmiah Sains. 2011;11(2)

16. Immamudin $\mathrm{H}$. Pola pertumbuhan dan toksisitas bakteri Resisten $\mathrm{HgCl}_{2}$. Jurnal EKOSAINS. 2010;2(1) 
17. Brooks FG. Butel SF. Morse AS. Mikrobiologi kedokteran Jawetz. Ed.23. Jakarta: EGC, 2007.

18. Anne O. Interaction of human commensal bacteria with amalgam-derived mercury: the scince and its implications for infectious disease and neurotoxicology. [Athens (GA)]:Georgia University; 2006. 


\section{LAMPIRAN GAMBAR HASIL PENELITIAN}

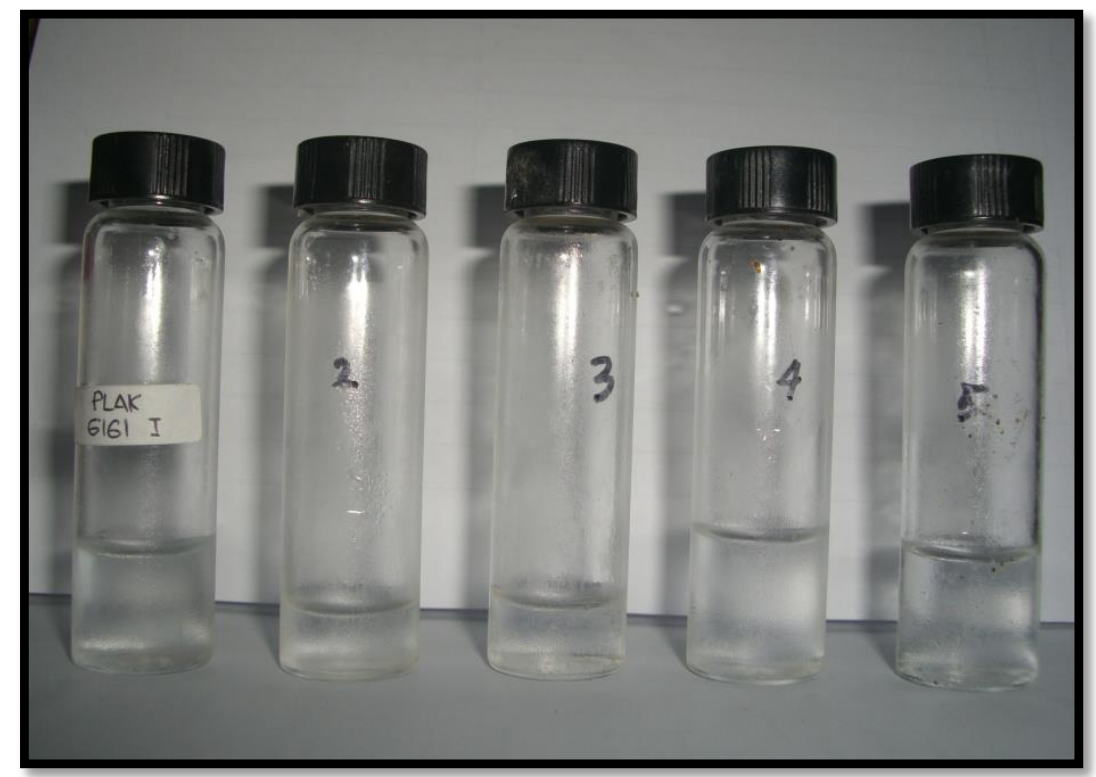

Gambar 1. Sampel Plak Gigi

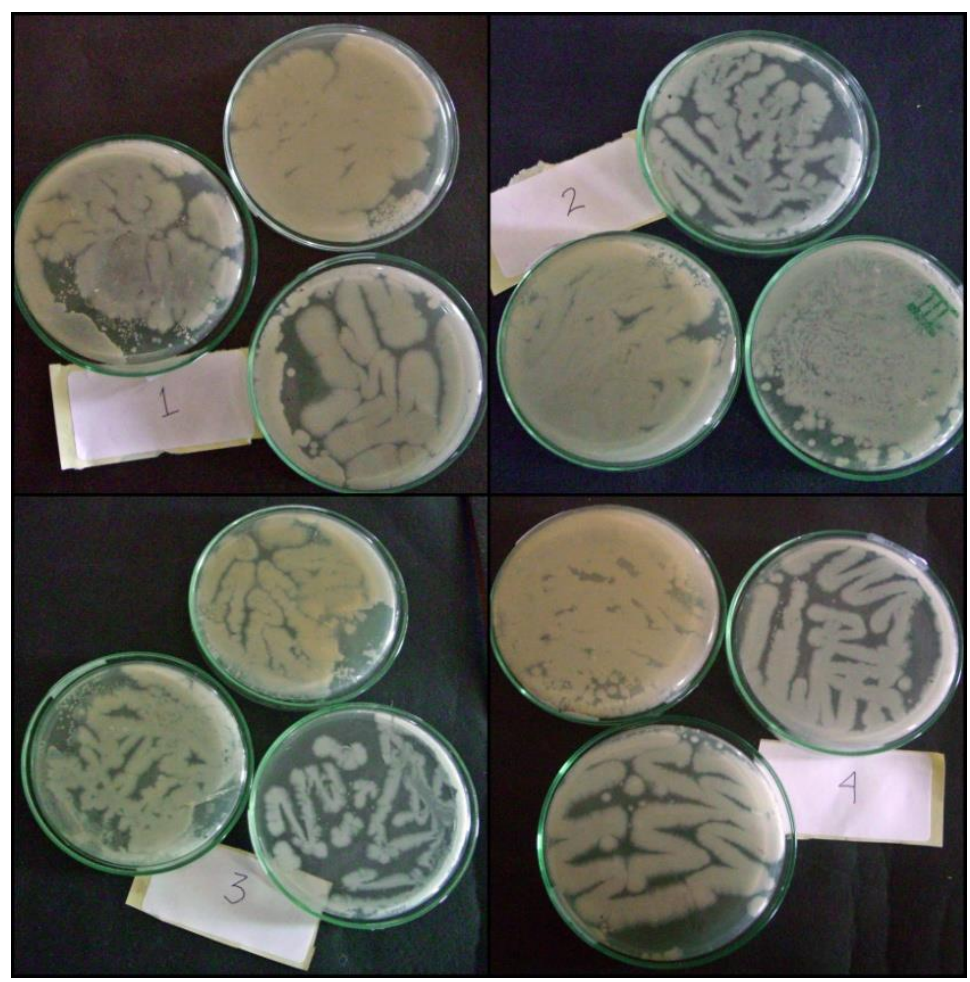

Gambar 2. Koloni Bakteri Murni 


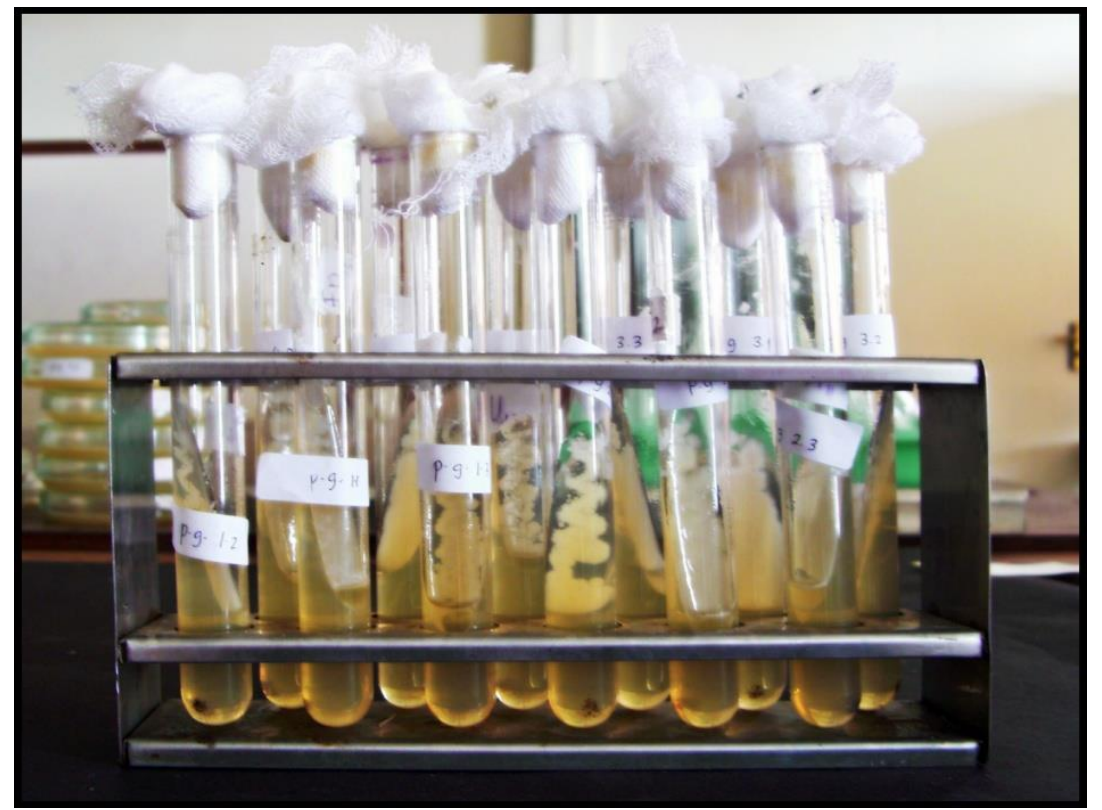

Gambar 3. Koloni Bakteri pada Media Agar miring

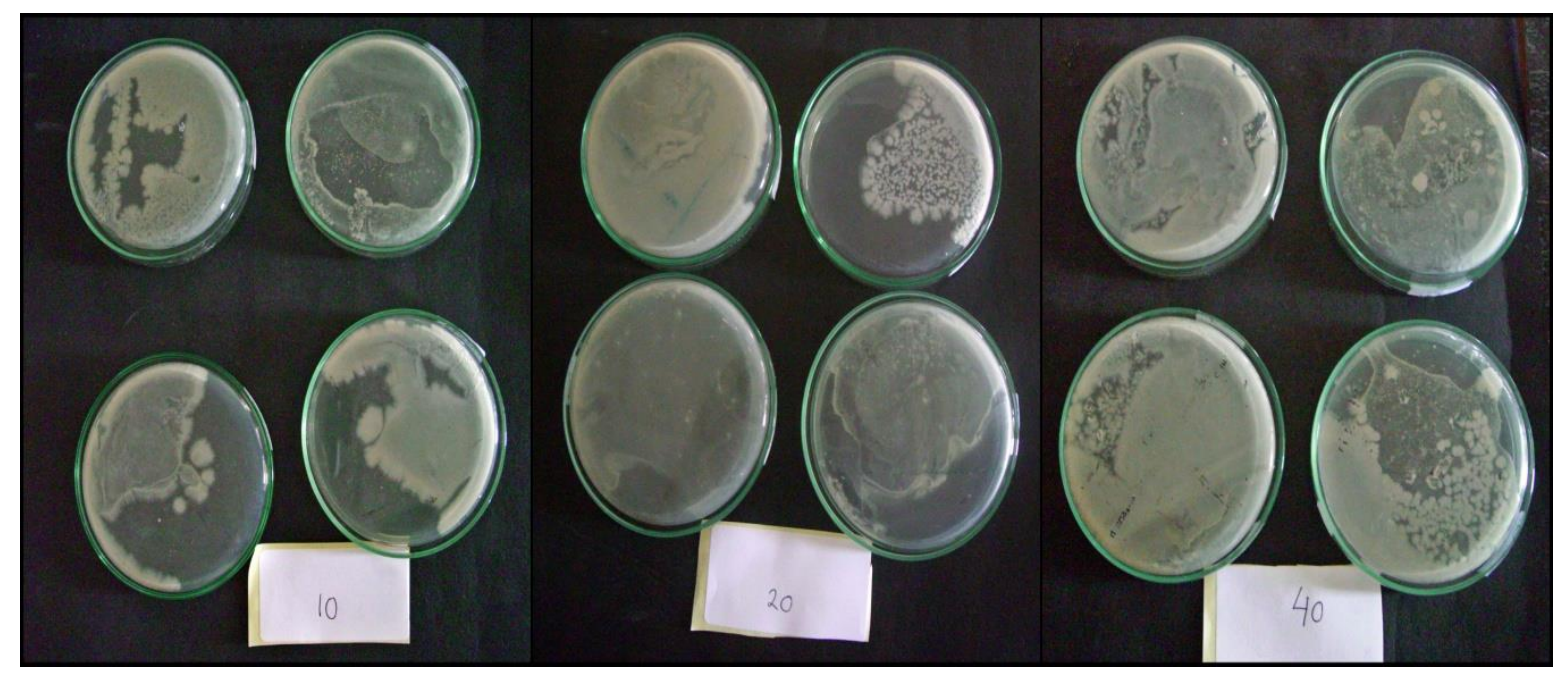

Gambar 4. Pertumbuhan Bakteri masing-masing pada Konsentrasi 10 ppm, 20 ppm, dan 40 ppm 


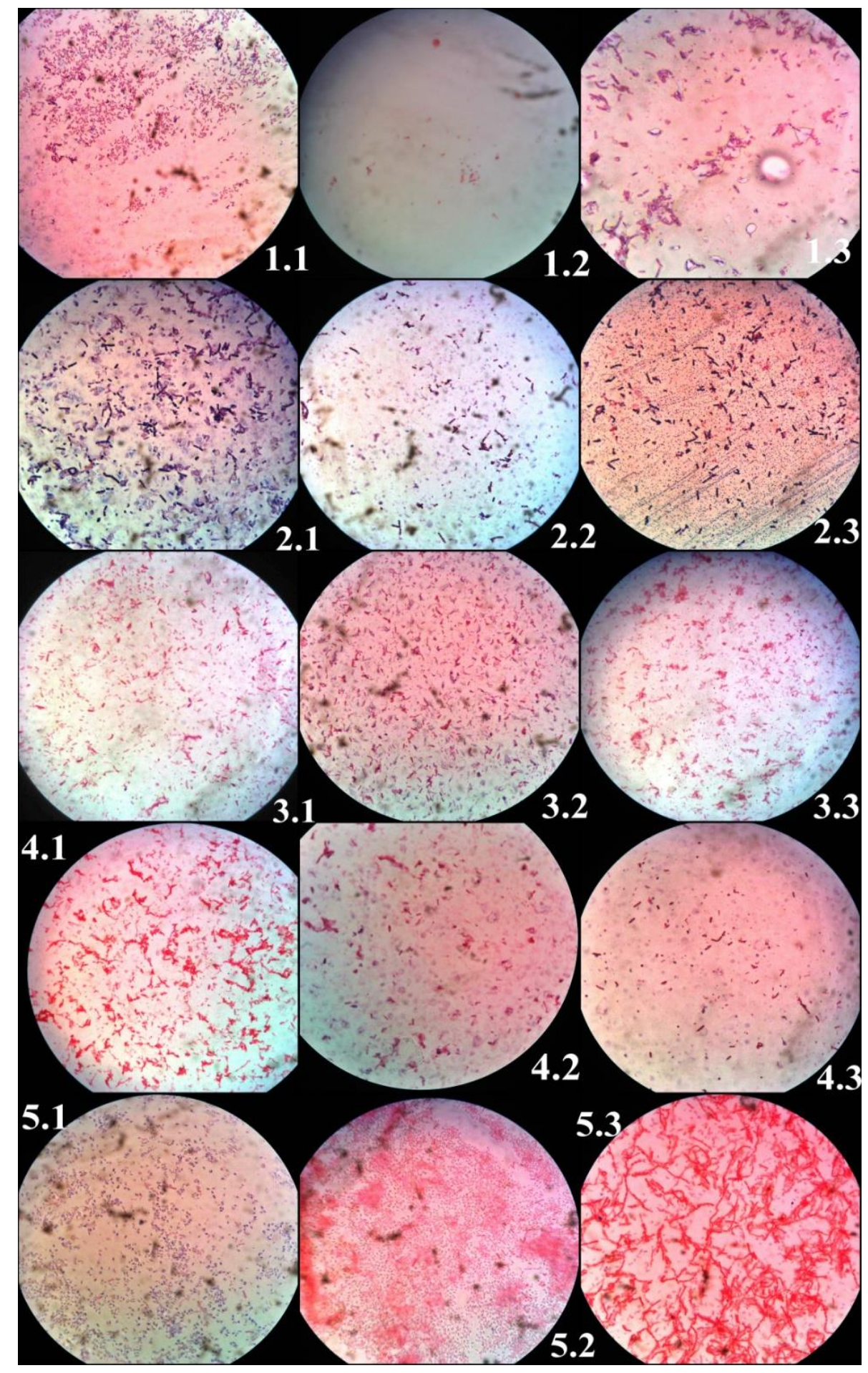

Gambar 5. Hasil Uji Morfologi Pewarnaan Gram 


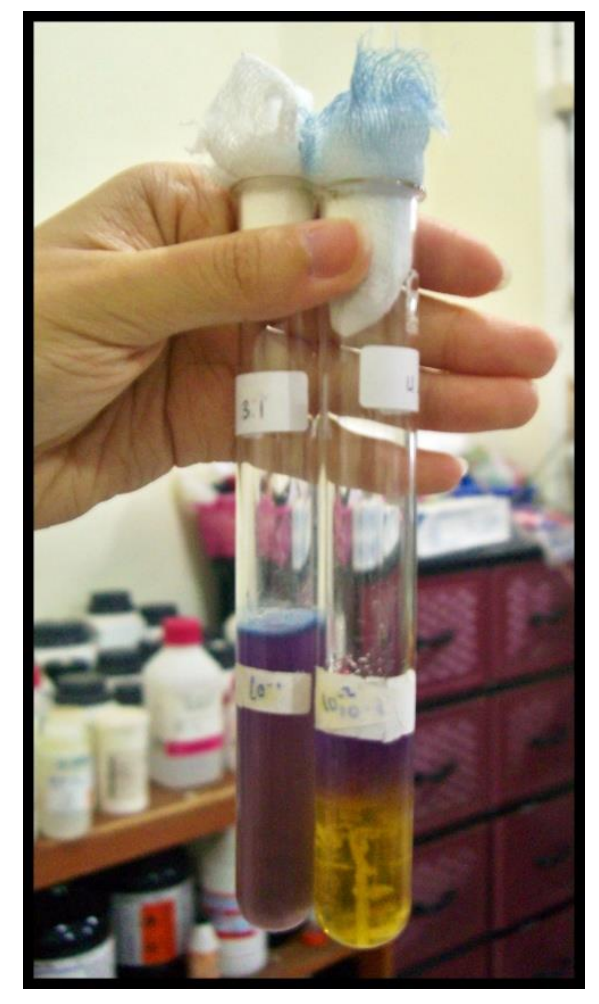

Gambar 6. Hasil Uji Fisiologi (motility test).

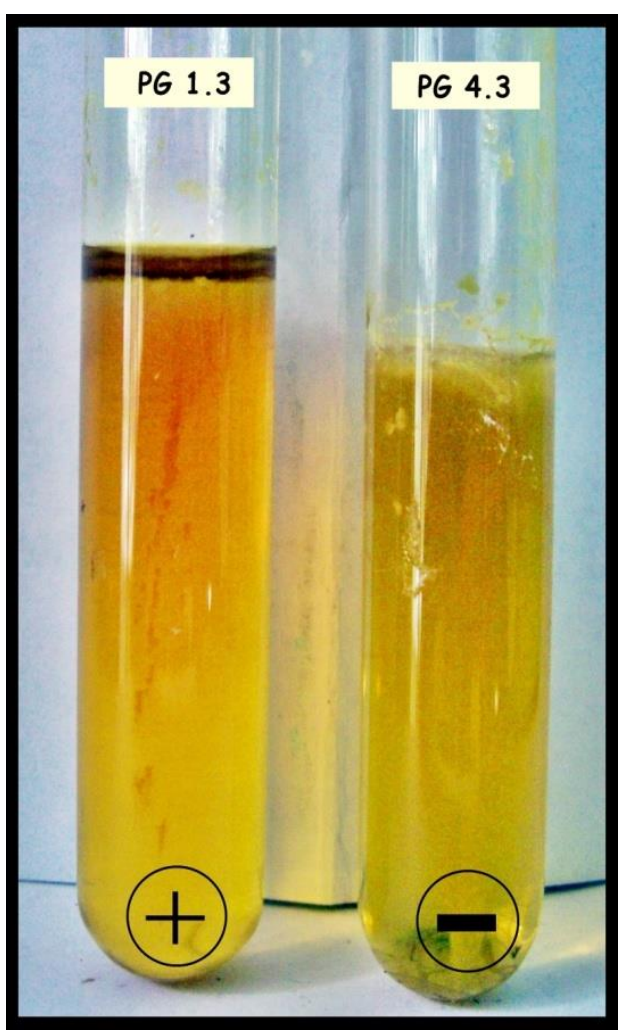

Gambar 7. Hasil Uji Indol. 

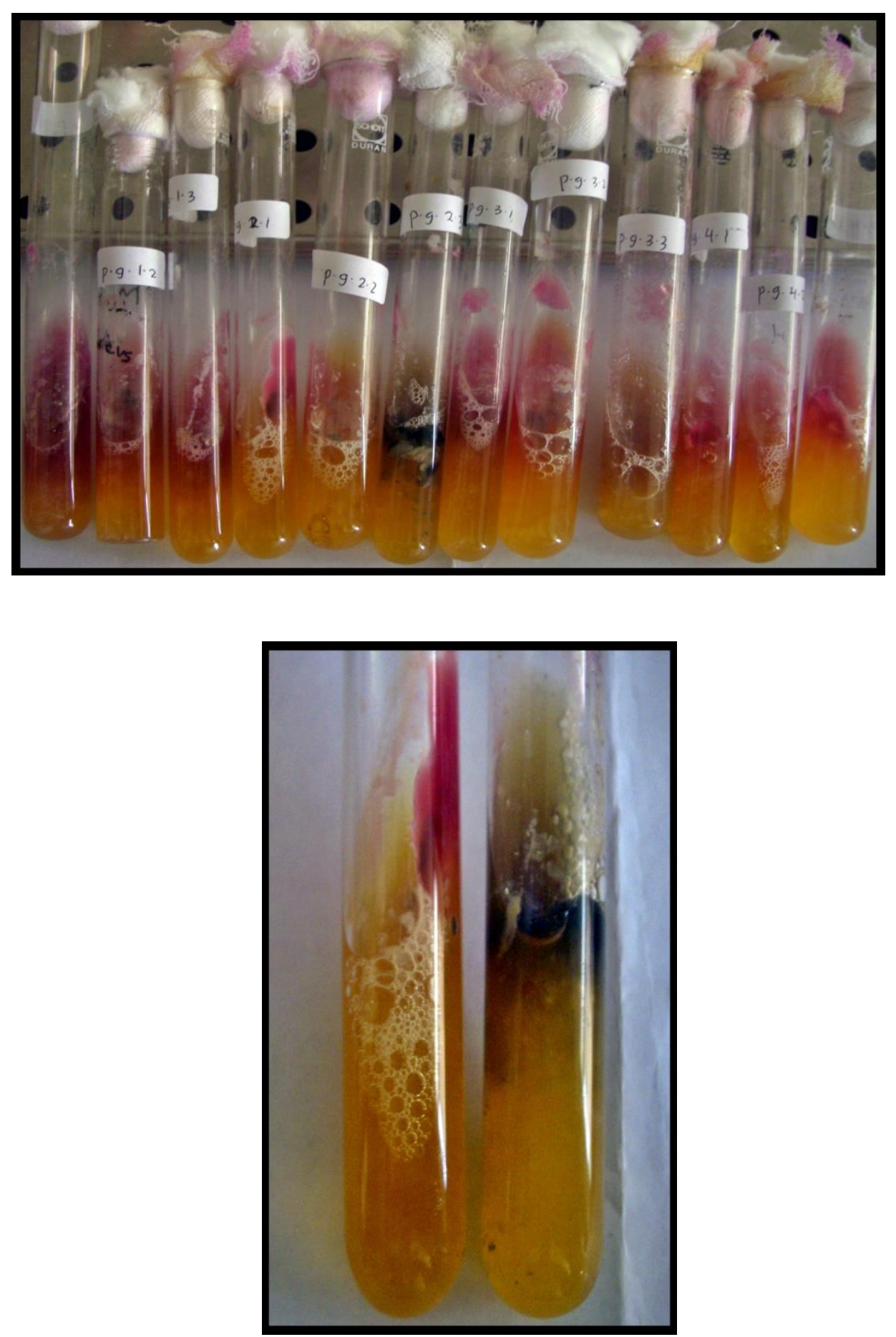

Gambar 8 dan 9. Hasil Fermentasi Karbohidrat dan $\mathrm{H}_{2} \mathrm{~S}$ 


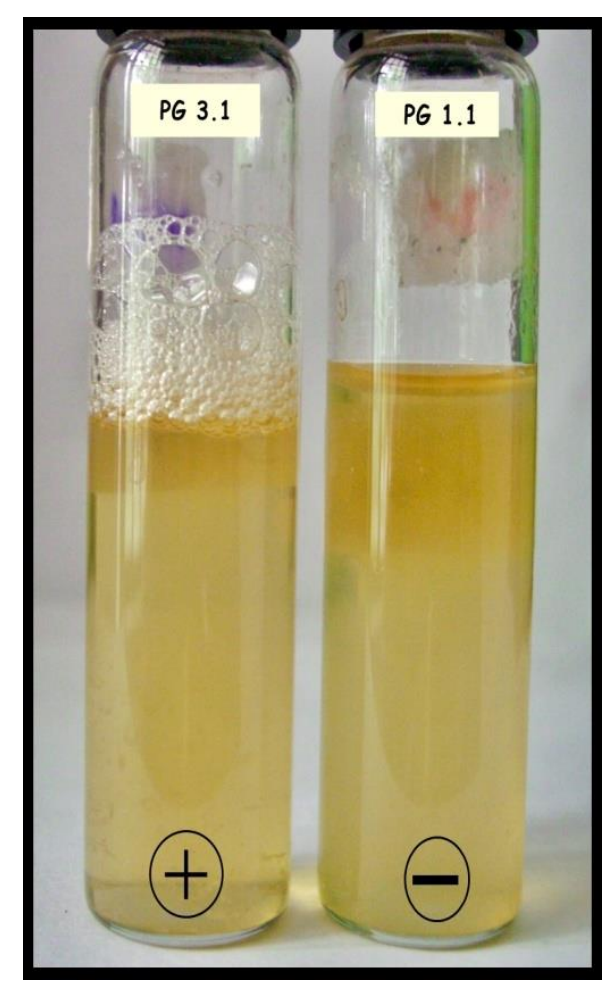

Gambar 10. Hasil Uji Katalase.

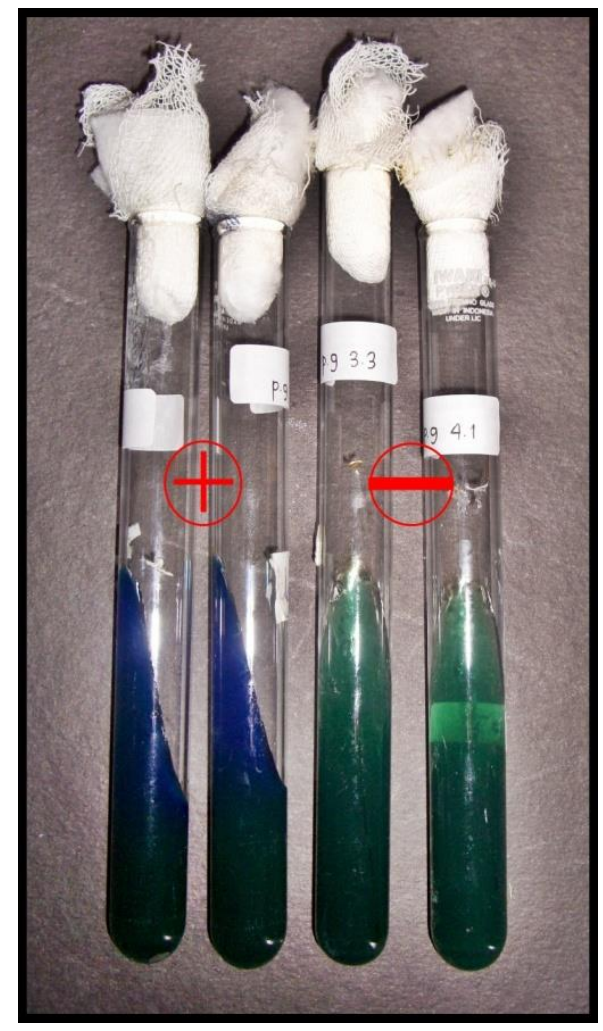

Gambar 11. Hasil Uji Sitrat 


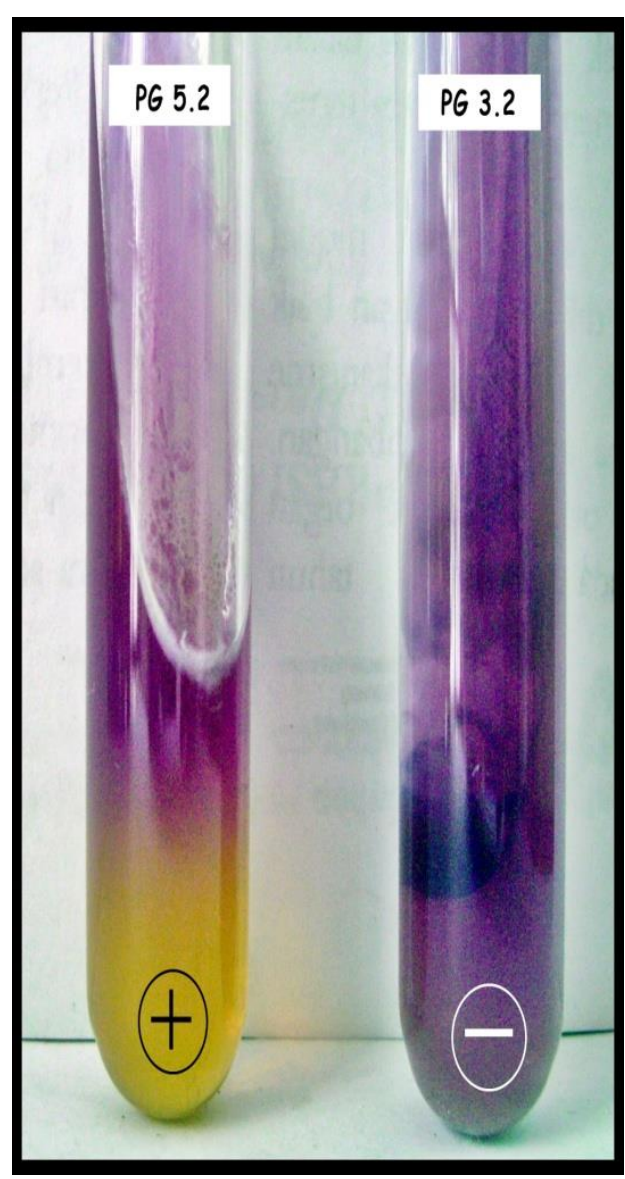

Gambar 12. Uji Lysine Dekarboksilase. 


\begin{tabular}{|c|c|c|c|c|c|c|c|c|c|c|}
\hline \multirow[b]{2}{*}{$\begin{array}{l}\text { Kode Uji } \\
\text { Isolat }\end{array}$} & \multicolumn{2}{|c|}{ Uji Morfologi } & \multirow[b]{2}{*}{$\begin{array}{l}\text { Uji Fisiologi } \\
\text { (motility test) }\end{array}$} & \multicolumn{6}{|c|}{ Uji Biokimia } & \multirow[b]{2}{*}{ Genus Bakteri } \\
\hline & $\begin{array}{c}\text { Pewarnaan } \\
\text { Gram }\end{array}$ & $\begin{array}{c}\text { Bentuk } \\
\text { Sel }\end{array}$ & & Uji Indol & $\mathrm{Uji} \mathrm{H}_{2} \mathrm{~S}$ & $\begin{array}{c}\text { Uji } \\
\text { Fermentasi } \\
\text { Karbohidrat }\end{array}$ & $\begin{array}{c}\text { Uji } \\
\text { Katalase }\end{array}$ & $\begin{array}{c}\mathrm{Uji} \\
\text { Sitrat }\end{array}$ & $\begin{array}{c}\text { Uji Lysine } \\
\text { Dekarboksilase }\end{array}$ & \\
\hline PG 1.1 & + & Kokus & - & + & - & - & - & - & + & $\begin{array}{c}\text { Gamella, Lactococcus, Pediococcus, } \\
\text { Sterptococcus }\end{array}$ \\
\hline PG 1.2 & - & Kokus & + & + & - & - & - & - & + & Acitenobacter \\
\hline PG 1.3 & + & Kokus & - & + & - & - & + & - & + & Staphylococcus \\
\hline PG 2.1 & + & Kokus & - & + & + & + & + & - & - & Staphylococcus \\
\hline PG 2.2 & + & Kokus & + & + & + & + & + & - & - & $\begin{array}{l}\text { Marinococcus, Micrococcus, } \\
\text { Planococcus }\end{array}$ \\
\hline PG 2.3 & + & Kokus & + & + & - & - & + & - & + & $\begin{array}{l}\text { Marinococcus, Micrococcus, } \\
\text { Planococcus }\end{array}$ \\
\hline PG 3.1 & - & Kokus & + & - & + & + & + & + & - & Alcaligenes \\
\hline PG 3.2 & + & Kokus & + & + & + & + & + & + & - & $\begin{array}{c}\text { Marinococcus, Micrococcus, } \\
\text { Planococcus }\end{array}$ \\
\hline PG 3.3 & - & Kokus & + & + & + & + & - & - & - & Acitenobacter \\
\hline PG 4.1 & - & Kokus & + & + & + & + & + & - & - & Acitenobacter \\
\hline PG 4.2 & - & Kokus & - & + & + & + & + & - & + & Morococcus \\
\hline PG 4.3 & - & Kokus & - & - & + & + & - & - & - & Phenylobacterium \\
\hline PG 5.1 & + & Kokus & + & + & + & + & + & - & + & $\begin{array}{l}\text { Marinococcus, Micrococcus, } \\
\text { Planococcus }\end{array}$ \\
\hline PG 5.2 & - & Kokus & - & + & + & - & - & - & + & Phenylobacterium \\
\hline PG 5.3 & - & Kokus & - & - & + & - & + & - & + & Brucella \\
\hline
\end{tabular}

Tabel Hasil Uji Morfologi, Uji Fisiologi, Uji Biokimia 